\title{
Pembuatan dan pelatihan website Koperasi Kelapa Sawit (KUD Milik Bersama) berbasis android di Desa Bukit Lingkar Kabupaten Indragiri Hulu
}

\author{
Roza Yulida*, Rosnita, Deby Kurnia, Yulia Andriani, \& Fanny Septya
}

Fakultas Pertanian, Universitas Riau

* roza.yulida@lecturer.unri.ac.id

\begin{abstract}
Abstrak. Website dapat menjadi pusat informasi dan komunikasi bagi koperasi bersama anggotanya dalam mempercepat arus informasi dan komunikasi pekebun kelapa sawit. Tujuan kegiatan pengabdian ini adalah membuat website KUD sebagai pusat informasi bagi koperasi dan anggotanya. Kegiatan pengabdian di laksanakan di Desa Bukit Lingkar yang merupakan salah satu desa dengan potensi kelapa sawit di Kabupaten Indragiri Hulu. Di Desa ini juga sudah berdiri Koperasi kelapa sawit dengan nama KUD Milik Bersama yang menjadi mitra pada kegiatan ini.Kegiatan diintegrasikan dengan Kukerta Mahasiswa di Desa Bukit Lingkar. Pelaksanaan kegiatan pelatihan dengan tahapan kegiatan sosialisasi dan diskusi dengan peserta dan praktek membuat dan menggunakan website, bantuan paket teknologi media website koperasi, serta dilanjutkan dengan tahap pembinaan. Teknis pelaksanaan kegiatan adalah kombinasi antara pelatihan dengan pertemuan daring mengingat masih masa pandemi covid 19 dan pelaksana di lapangan adalah mahasiswa kukerta. Hasil dari kegiatan ini antara lain, terbentuknya website koperasi dengan nama http://www.koperasi kudmilikbersama.com, meningkatnya pengetahuan dan keterampilan pekebun tentang penggunaan media termasuk website dengan informasi yang terkait dengan usahatani kelapa sawit. Terbentuknya pengelola website, yang dilengkapi dengan modul website.
\end{abstract}

Kata kunci: website, teknologi, pekebun kelapa sawit , koperasi unit desa,

\begin{abstract}
The website can be a center of information and communication for them. It is accelerating the flow of information and communication on oil palm growers. The purpose of this service activity is to create an android-based KUD website which contains information about cooperatives and information about oil palm plantations. Community service activities are carried out in Bukit Lingkar Village, one of potential villages in oil palm. In this village, an oil palm village cooperative with the name KUD Milik Bersama has also been established which is a partner in this activity. Activities are integrated with the Student project. Implementation of training activities is socialization and discussion activities. then practice making websites, assistance and coaching. The technical implementation of the activity is a combination of offline and online meetings. It is because Covid 19 pandemic. The implementers in the field are students. The results of this activity include the formation of a cooperative website with the name http: //www.koperasi kudmilikbersama.com, increasing farmers' knowledge and skills regarding media use, including a website with information related to oil palm farming. The establishment of a website manager, which is equipped with a website module.
\end{abstract}

Keywords: website, technology, oil palm farmers, village cooperative

To cite this article: Yulida, R., Rosnita., D. Kurnia., Y. Andriani., \& F. Septya. 2020. Pembuatan dan pelatihan website Koperasi Kelapa Sawit (KUD Milik Bersama) berbasis android di Desa Bukit Lingkar Kabupaten Indragiri Hulu. Unri Conference Series: Community Engagement 2: 416-422. https://doi.org/10.31258/unricsce.2.416-422

(C) 2020 Authors

Peer-review under responsibility of the organizing committee of Seminar Nasional Pemberdayaan Masyarakat 2020 


\section{PENDAHULUAN}

Dewasa ini perkembangan teknologi informasi yang semakin hari semakin pesat berdampak pada perilaku banyak orang yaitu untuk dapat memenuhi kebutuhan informasi yang lebih cepat dan murah tentunya, selain itu menuntut juga para pemberi informasi untuk memiliki sebuah media online, dimana informasi yang disajikan bisa dengan mudah dan cepat didapatkan oleh konsumen informasi. Teknologi informasi dan komunikasi memberikan banyak kemudahan dan membantu memperlancar segala aktivitas manusia, termasuk bidang pertanian (Adinata, dkk, 2019).

Kelapa sawit merupakan tumbuhan industri penting penghasil minyak industri, maupun bahan bakar (biodiesel). Komoditas perkebunan kelapa sawit menghasilkan keuntungan yang besar sehingga banyak hutan dan perkebunan lama dikonversi menjadi perkebunan kelapa sawit.Kabupaten Indragiri Hulu umumnya dan Desa Bukit Lingkar khususnya sebagai wilayah dengan potensi utamanya adalah kelapa sawit, sektor pertanian selayaknya dapat memberikan kontribusi yang cukup besar.

Hal ini akan sangat berperan bagi perkebunan untuk mengikuti perkembangan teknologi usaha tani yang begitu cepat berkembang. Pekebun kelapa sawit yang mampu memanfaatkan teknologi informasi seperti penggunaan smartphone atau media internet untuk mencari informasi dan menggunakannya dalam kegiatan usaha tani, tentu akan berbeda dengan pekebun yang tidak memiliki kemampuan untuk itu. Asosiasi Penyelenggara Jasa Internet Indonesia (APJII) menyatakan bahwa 51,8\% masyarakat indonesia telah menggunakan internet saat ini sudah menjadi sarana bagi masyarakat. Media digital menjadi sarana bagi masyarakat untuk melakukan promosi. (Riyanto dan Noeris, 2018). Perkembangan teknologi informasi telah memunculkan berbagai berbagai kegiatan yang mem, memanfaatkan teknologi informasi dan komunikasi, seperti e-government, e-commerce, e-education dan lain sebagainya (Ferdinandus dan Wijaya, 2020).

Kemampuan penggunaan teknologi informasi dan komunikasi bagi perkebunan ini menjadi gambaran bagaimana kemampuan perkebunan dalam mengikuti perkembangan teknologi informasi dan komunikasi, terutama kemampuan memanfaatkan media dalam kaitannya mencari dan memanfaatkan informasi usaha tani kelapa sawit.Salah satu media komunikasi yang saat ini sangat berkembang adalah komunikasi dengan menggunakan internet seperti media Website. Media website dapat menjadi sarana penyebar informasi dan peningkatan pendapatan UMKM. Fitur-fitur yang terdapat di website memudahkan UMKM melakukan transaksi pemasaran dengan konsumen, seperti pemesanan, dan pengembangan produk (Darnis dan Azdy, 2019). Website dapat digunakan untuk memperluas dan mempermudah mitra dalam mempromosikan dan memasarkan produk-produknya (Bukit, dkk., 2019).

Website ini dapat diakses melalui mobile communication (Komunikasi Bergerak) seperti Handphone/smartphone kita pun dapat berkomunikasi dengan siapapun, dimanapun, dan kapanpun melalui media internet. Meskipun para petani sawit mempunyai grup whatsapp yang digunakan untuk saling membagi informasi tentang pertanian sawit seperti harga namun hal tersebut tentu masih kurang apalagi tingkat keamanan dari whatsapp sendiri yang masih kurang, untuk itulah diperlukan suatu media informasi yang mempunyai keamanan yang cukup bagus salah satunya Website. Adanya website pada lembaga KUD telah mampu meningkatkan literasi media pekebun kelapa sawit di Desa Kiyap Jaya Kabupaten Pelalawan. (Yulida et al., 2020). Media website telah mampu membuka peluang yang besar bagi petani dalam mengakses informasi dan melakukan pemasaran ke luar Provinsi Jambi (Nurfathiyah dan Aminoto, 2018). Kemudahan masyarakat mencari informasi dan mengenal desa, merupakan keunggulan menggunakan website sebagai wadah promosi potensi dan produk desa (Desiani, dkk, 2020)

Koperasi Unit Desa (KUD) secara umum bergerak di wilayah pedesaan.Dimana koperasi ini dibentuk untuk memenuhi kebutuhan masyarakat desa dalam aktivitas pertanian karena kebanyakan masyarakat desa bekerja di sektor agraria atau pertanian. Melalui KUD inilah masyarakat desa melakukan aktivitas simpan pinjam, pemasaran, layanan jasa, kegiatan konsumsi maupun produksi hasil usaha.KUD bisa diibaratkan wadah organisasi ekonomi sosial kemasyarakatan. Karna peran KUD sebagai wadah organisasi ekonomi sosial kemasyarakatan yang memuat informasi terkait kebutuhan para pekebun kelapa sawit di tuntut untuk membuat inovasi baru seperti website yang dapat diakses dimanapun, dan kapanpun oleh masyarakat khususnya kelompok tani kelapa sawit. Oleh karena itu tujuan dari kegiatan pengabdian ini adalah membantu membuat website koperasi, melatih anggota koperasi menggunakan website, serta membentuk pengelola website koperasi.

Oleh karena itu mahasiswa Kukerta Terintegrasi sebagai agen of change yang memiliki kemampuan dan wawasan yang lebih serta menjadi salah satu sumber ilmu bagi masyarakat dapat berkontribusi membantu 
masyarakat dalam meningkatkan Kemampuan penggunaan teknologi informasi dan komunikasi melalui website untuk membantu mendukung perkembangan teknologi dan mendapatkan informasi dengan cepat.

\section{METODE PENERAPAN}

Kegiatan ini diawali dengan melakukan survei lokasi Kukerta terkait tepat atau tidaknya dilakukan program pembuatan website ini ke Desa tersebut.Selanjutnya Pelatihan website kepada mahasiswa kukerta terintegrasi yang dilaksanakan di awal masa kukerta yaitu sebelum mahasiswa kukerta turun ke Desa tempat kukerta.Kemudian Pembuatan website, pengumpulan data-data yang dibutuhkan, menginput data ke dalam website, peluncuran website serta pelatihan website kepada admin yang telah ditunjuk dalam mengelola website dan pelatihan penggunaan website kepada kelompok tani.Adapun metode yang digunakan dalam kegiatan pengabdian masyarakat ini yaitu :

1. Pengenalan dan pelatihan website kepada mahasiswa

Kegiatan ini diawali dengan penjelasan oleh pelatih kepada mahasiswa kukerta terkait apa itu website dan bagian-bagiannya. Selain penjelasan pelatih juga memperlihatkan langsung bagian-bagian dari website. Adapun dalam kegiatan pelatihan ini mahasiswa kukerta dilatih untuk membuat 2 (dua) model website yaitu website online dan offline.

2. Pembuatan website oleh mahasiswa kukerta

Setelah melakukan pelatihan selanjutnya yaitu pembuatan website yang dilakukan oleh mahasiswa kukerta.Kegiatan ini dilakukan dengan bimbingan dari pelatih, jika mahasiswa kukerta tidak tahu atau pun lupa maka dapat bertanya kepada pelatih. Dalam pembuatan website ini diajarkan tata cara melakukan perubahan atau mengedit tampilan-tampilan website.

3. Penginputan data yang dibutuhkan. Kegiatan ini lakukan setelah website terbentuk maka data-data yang telah ada dimasukan ke dalam website.

4. Peluncuran website

Kegiatan ini diawali dengan pembukaan dan penjelasan singkat terkait website yang ada dan bagian-bagian yang ada dalam website, selanjutnya penyerahan website kepada Koperasi yang dilakukan oleh DPL.

5. Pelatihan pengelolaan dan manajemen website kepada Admin

Setelahnya peluncuran baru lah dilakukan pelatihan penggunaan website dan tata cara memasukan data ataupun meng update informasi ke dalam website yang dilakukan langsung oleh mahasiswa kukerta kepada admin yang telah ditunjuk.

\section{HASIL DAN KETERCAPAIAN SASARAN}

Dalam pelaksanaan kegiatan pembuatan website ini dimulai dengan melakukan survei ke lokasi kukerta yang dilaksanakan pada minggu ketiga bulan juni tepatnya tanggal tanggal 15 juni. Awalnya desa Kukerta terletak di Desa Kenantan Kec. Tapung Kab. Kampar. Namun karena terjadi pandemi covid 19, lokasi kukerta dianjurkan adalah lokasi desa asal mahasiswa yang dilibatkan. Sedangkan Mahasiswa yang dilibatkan tidak ada yang berasal dari Desa Kinantan. Maka lokasi kegiatan dipindahkan ke desa mahasiswa yang dilibatkan dan terdapat koperasi sebagai mitra kegiatan, yaitu Desa Bukit Lingkar.

Setelah melakukan survei lokasi kegiatan dilanjutkan dengan pengenalan dan pelatihan pembuatan website kepada mahasiswa kukerta dan dilatih oleh tim Dosen Pembimbing Lapangan (DPL). Selanjutnya kegiatan dilanjutkan dengan pembuatan website yang dilakukan oleh mahasiswa kukerta setelah memahami dan mengetahui terkait website itu sendiri.

Kemudian kegiatan dilanjutkan dengan Pengumpulan data-data yang dibutuhkan untuk website, proses pengumpulan data ini dilakukan di Kantor Koperasi Unit Desa langsung. Penginputan data kedalam website, setelah melakukan pengumpulan data-data yang dibutuhkan selanjutnya data tersebut diinput ke dalam website. Setelah pengumpulan berbagai data-data maka website siap untuk peluncuran dan pelatihan kepada admin untuk mengelola website tersebut. Dalam memilih admin Tim Kukerta dan DPL berkoordinasi dengan Petugas Penyuluh Lapangan (PPL) untuk menentukan siapa yang akan menjadi admin. Selain melakukan pelatihan kepada admin, juga dilakukan pelatihan pengaplikasian website kepada kelompok tani dan masyarakat terkait tata cara membuka website untuk membaca informasi-informasi yang disajikan.Tindak lanjut dari program pembuatan website ini adalah masyarakat mampu membaca informasi yang ada di website tersebut sehingga membantu meningkatkan pemahaman petani kelapa sawit tentang informasi terbaru seputar 
kelapa sawit dan pentingnya teknologi dalam menunjang penyebaran informasi tersebut dan admin telah dilatih dan mampu untuk mengelola website.

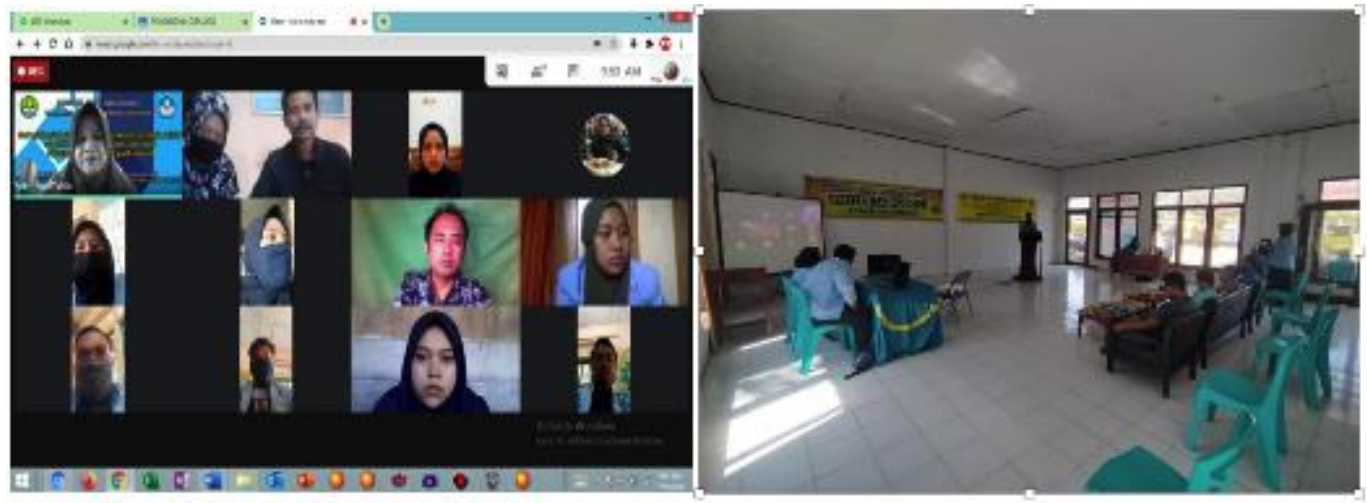

Gambar 1 dan 2. Penyuluhan dan Launching Website KUD Milik Bersama

Kegiatan pembuatan website koperasi Berkat Bersama di Desa Bukit Lingkar Kecamatan Batang Cenaku Kabupaten Indragiri Hulu, sudah sampai pada tahap proses penyelesaian website. Website koperasi berkat bersama sudah diselesaikan atas kerjasama yang saling mendukung antara tim dosen pengabdian, mahasiswa kukerta dan koperasi Berkat Bersama, dengan link website koperasi http://www.kudmilikbersama.com.

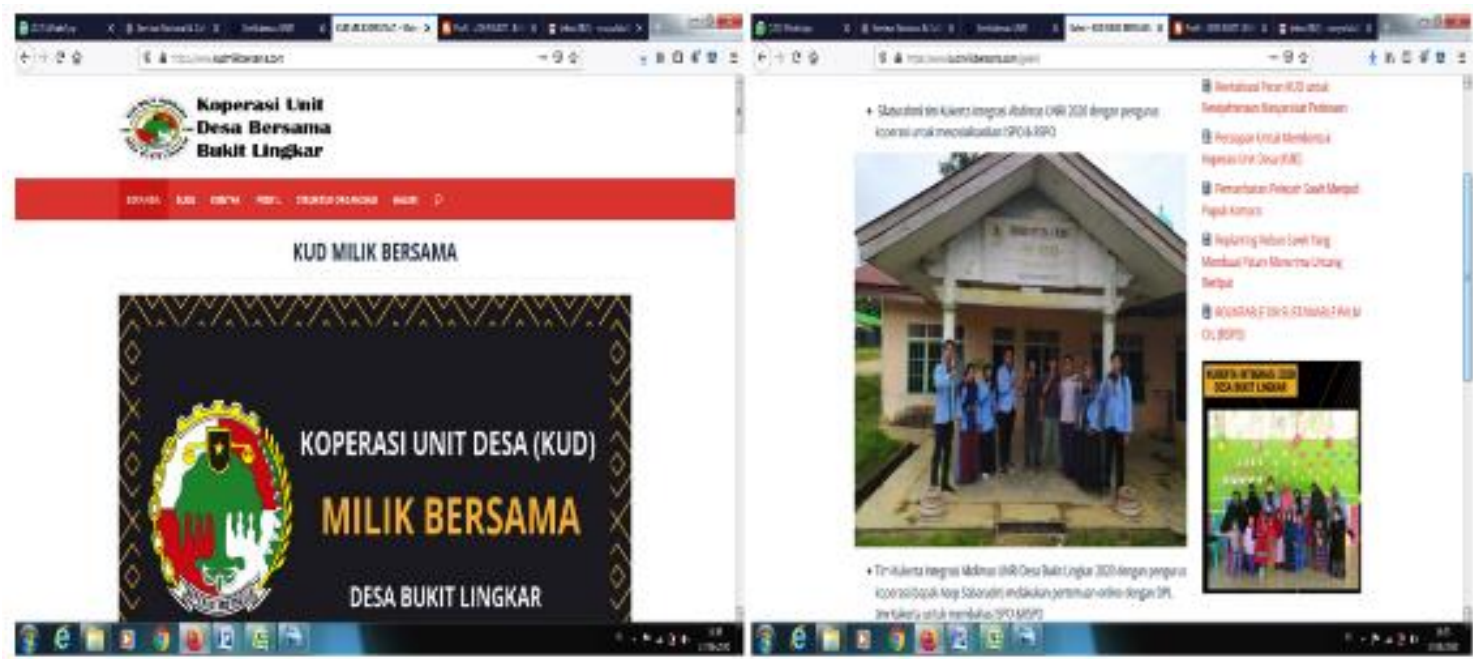

Gambar 3 dan 4. Tampilan website koperasi milik Bersama

Website koperasi yang dibuat berbasiskan android, sehingga pekebun kelapa sawit atau siapapun yang ingin mengakses informasi di website koperasi tersebut akan dapat membukanya dengan mudah di smartphone atau android mereka, dimana saja dan kapan saja. Android memungkinkan penggunanya mengeksplorasi kemampuan dan menambah pengalaman lebih dibandingkan dengan platform mobile lainnya (Putera, Irwansyah, dan Sukamto, 2017).

Website ini dibuat dengan tujuan sebagai wadah bagi pekebun kelapa sawit untuk mendapatkan informasi tentang kelapa sawit. Oleh karena itu website koperasi ini dilengkapi dengan informasi-informasi terkait dengan kelapa sawit. Informasi-informasi ini akan sangat bermanfaat bagi pekebun kelapa sawit yang selama ini tidak memahami dimana bisa mendapatkan informasi tentang kelapa sawit. Terutama informasi yang terkait dengan standar nasional dan internasional kelapa sawit. Website (desa) sebagai sarana informasi, layanan dan dapat sebagai wadah pengarsipan bagi lembaga (desa) (Sutrisno dan Trisnawarman, 2018). 


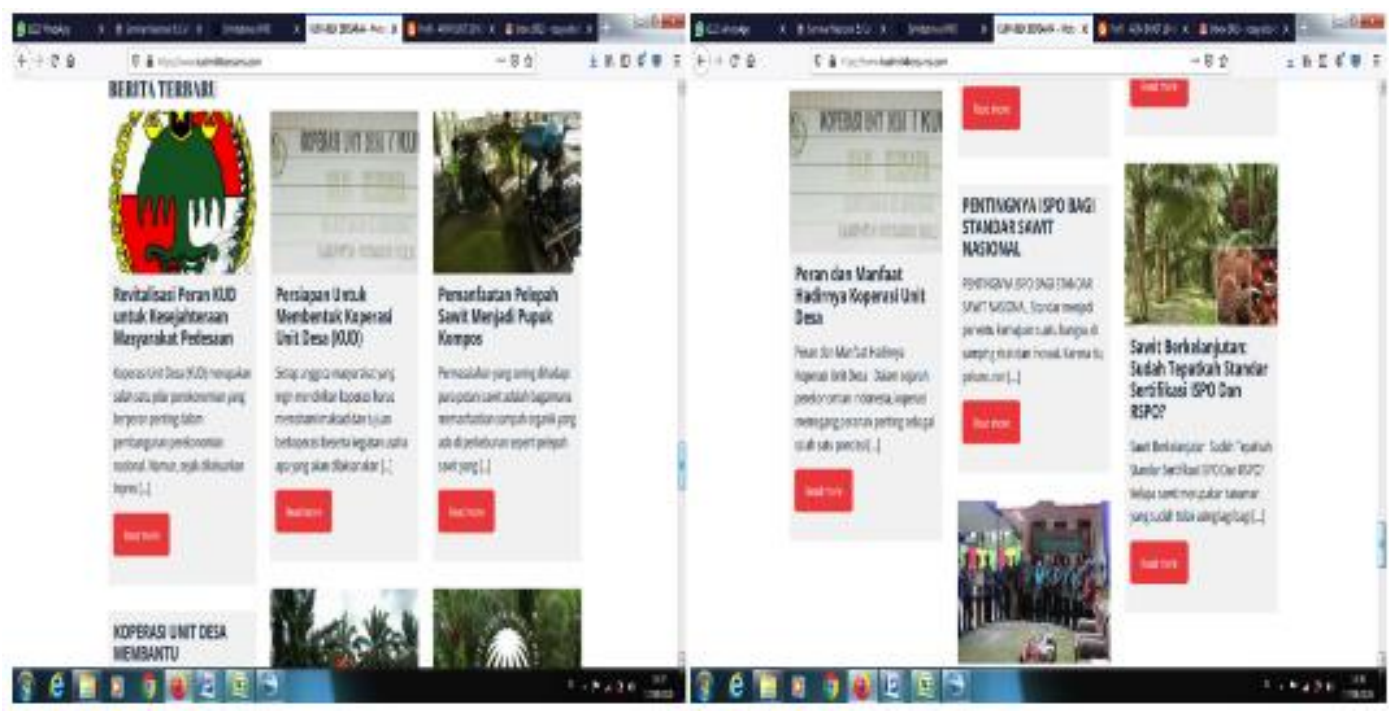

Gambar 5 dan 6. Beberapa informasi yang ditampilkan di website Koperasi Berkat Bersama

Website koperasi yang berbasis android yang dibuat telah mampu meningkatkan pengetahuan pekebun kelapa sawit tentang kelapa sawit. Kemudahan pekebun mengakses informasi melalui smartphone yang mereka miliki dimana saja dan kapan saja menjadi kekuatan dalam penggunaan website ini. Melalui website koperasi bersama anggotanya telah mampu melakukan komunikasi dan menambah pengetahuan terkait usahatani kelapa sawit, seperti tentang standar nasional dan internasional kelapa sawit, peremajaan kelapa sawit, dan informasi lainnya yang ditampilkan di dalam website. Website lebih mudah diakses oleh masyarakat, sebagai wadah pemasaran, informasi, pendidikan, komunikasi dan promosi (Hasugian, 2018).

Tabel 1. Kondisi peserta sebelum dan sesudah pelatihan

\begin{tabular}{|c|c|c|c|}
\hline Kriteria & Indikator & Sebelum & Sesudah \\
\hline \multirow[t]{4}{*}{$\begin{array}{l}\text { Kemampuan teknis } \\
\text { menggunakan media }\end{array}$} & $\begin{array}{l}\text { a. Kemampuan teknis } \\
\text { menggunakan } \\
\text { smartphone }\end{array}$ & $\begin{array}{l}60 \% \text { sudah mampu } \\
\text { menggunakan smartphone }\end{array}$ & $\begin{array}{l}70 \% \text { sudah mampu } \\
\text { menggunakan smartphone }\end{array}$ \\
\hline & $\begin{array}{l}\text { b. Kemampuan teknis } \\
\text { menggunakan internet }\end{array}$ & $\begin{array}{l}50 \% \text { sudah tahu teknis } \\
\text { menggunakan internet }\end{array}$ & $\begin{array}{l}70 \% \text { sudah tahu teknis } \\
\text { menggunakan internet }\end{array}$ \\
\hline & $\begin{array}{l}\text { c. Kemampuan } \\
\text { menggunakan teknis } \\
\text { media sosial }\end{array}$ & $\begin{array}{l}60 \% \text { sudah tahu teknis } \\
\text { menggunakan media sosial } \\
\text { seperti whatsApp dan } \\
\text { Facebook }\end{array}$ & $\begin{array}{l}70 \% \text { sudah tahu teknis } \\
\text { menggunakan media sosial } \\
\text { seperti whatsApp dan } \\
\text { Facebook }\end{array}$ \\
\hline & $\begin{array}{l}\text { d. Kemampuan teknis } \\
\text { menggunakan website }\end{array}$ & $\begin{array}{l}0 \% \text { tahu mencari informasi } \\
\text { menggunakan website }\end{array}$ & $\begin{array}{l}60 \% \text { tahu teknis mencari } \\
\text { informasi menggunakan } \\
\text { website }\end{array}$ \\
\hline \multirow[t]{2}{*}{$\begin{array}{l}\text { Pengetahuan tentang } \\
\text { konten dan fungsi } \\
\text { media }\end{array}$} & $\begin{array}{l}\text { a. Pengetahuan tentang } \\
\text { media sosial }\end{array}$ & $\begin{array}{l}60 \% \text { sudah memiliki } \\
\text { pengetahuan tentang media } \\
\text { sosial, seperti WhatsApp } \\
\text { dan Facebook }\end{array}$ & $\begin{array}{l}90 \% \text { sudah memiliki } \\
\text { pengetahuan yang cukup } \\
\text { tentang media sosial, } \\
\text { seperti WhatsApp dan } \\
\text { Facebook }\end{array}$ \\
\hline & $\begin{array}{l}\text { b.Pengetahuan tentang } \\
\text { konten dan fungsi } \\
\text { internet }\end{array}$ & $\begin{array}{l}60 \% \text { sudah paham tentang } \\
\text { konten dan fungsi internet }\end{array}$ & $\begin{array}{l}80 \% \text { sudah paham tentang } \\
\text { konten dan fungsi internet }\end{array}$ \\
\hline
\end{tabular}




\begin{tabular}{|c|c|c|c|}
\hline & $\begin{array}{l}\text { c. Pengetahuan } \\
\text { menggunakan website }\end{array}$ & $\begin{array}{l}10 \% \text { memiliki pengetahuan } \\
\text { tentang menggunakan } \\
\text { website }\end{array}$ & $\begin{array}{l}60 \% \text { memiliki cukup } \\
\text { pengetahuan tentang } \\
\text { menggunakan website } \\
\text { KUD }\end{array}$ \\
\hline \multirow[t]{4}{*}{$\begin{array}{l}\text { Kemampuan } \\
\text { berkomunikasi atau } \\
\text { mendapatkan } \\
\text { informasi melalui } \\
\text { media }\end{array}$} & $\begin{array}{l}\text { d. Keaktifan } \\
\text { berkomunikasi } \\
\text { menggunakan media } \\
\text { sosial }\end{array}$ & $\begin{array}{l}60 \% \text { sudah biasa } \\
\text { berkomunikasi } \\
\text { menggunakan media sosial, } \\
\text { seperti WhatsApp dan } \\
\text { Facebook }\end{array}$ & $\begin{array}{l}70 \% \text { sudah biasa } \\
\text { berkomunikasi } \\
\text { menggunakan media sosial, } \\
\text { seperti WhatsApp dan } \\
\text { Facebook untuk mencari } \\
\text { informasi }\end{array}$ \\
\hline & $\begin{array}{l}\text { e. Keaktifan } \\
\text { menggunakan internet }\end{array}$ & $\begin{array}{l}50 \% \text { yang aktif } \\
\text { menggunakan internet }\end{array}$ & $\begin{array}{l}70 \% \text { yang aktif } \\
\text { menggunakan internet }\end{array}$ \\
\hline & $\begin{array}{l}\text { f. Keaktifan } \\
\text { menggunakan website }\end{array}$ & $\begin{array}{l}\text { Tidak ada yang aktif } \\
\text { menggunakan website }\end{array}$ & $\begin{array}{l}60 \% \text { aktif menggunakan } \\
\text { website }\end{array}$ \\
\hline & $\begin{array}{l}\text { i. Kemampuan/ } \\
\text { pengalaman } \\
\text { mengkreasikan dan } \\
\text { mengelola website }\end{array}$ & $\begin{array}{l}\text { Tidak ada peserta yang } \\
\text { memiliki pengalaman } \\
\text { tentang mengelola website }\end{array}$ & $\begin{array}{l}10 \% \text { peserta telah memiliki } \\
\text { kemampuan mengelola } \\
\text { website (terbentuknya } \\
\text { pengelola website) }\end{array}$ \\
\hline
\end{tabular}

Untuk memudahkan pekebun dalam mengelola dan menggunakan website dan supaya website dapat digunakan oleh seluruh anggota koperasi, hasil dari kegiatan ini juga menyediakan modul website koperasi yang dapat digunakan oleh koperasi bersama anggotanya. Hal ini juga dimaksudkan supaya website dapat digunakan secara berkelanjutan.

\section{KESIMPULAN}

Keberadaan website koperasi yang berbasis android sangat penting untuk meningkatkan pengetahuan pekebun kelapa sawit di Desa Bukit Lingkar untuk mengakses informasi seputar perkebunan kelapa sawit dan membantu masyarakatnya dalam mengikuti perkembangan teknologi informasi dan komunikasi. Diharapkan dari kegiatan ini dapat mempercepat pembangunan perkebunan di Desa Bukit Lingkar Khususnya dan Provinsi Riau Umumnya.

\section{UCAPAN TERIMA KASIH}

Terima kasih diucapkan kepada Lembaga Penelitian dan Pengabdian Masyarakat (LPPM) Universitas Riau.

\section{DAFTAR PUSTAKA}

Adinata IMRS, Tolle H, Brata AH. 2019. Pembangunan Aplikasi Penjualan Hasil Panen Kelompok Tani untuk Konsumen Berbasis Android dengan Metode Prototyping (Studi Kasus: Kelompok Tani Langgeng Mandiri). Jurnal Pengembangan Teknologi Informasi dan Ilmu Komputer, 3(7), 6378-6385. http://j-ptiik.ub.ac.id

Bukit FRA, Geby G, A.S, Irvan dan Fahmi. 2019. Pembuatan Website Katalog Produk Umkm Untuk Pengembangan Pemasaran Dan Promosi Produk Kuliner. Jurnal Pengabdian Dan Pemberdayaan Masyarakat, 3(2).

Desiani, A., Yahdin, S., Irmeilyana, \& Rodiah, D. 2020. Inovasi digitalisasi promosi potensi dan produk usaha masyarakat desa berbasis website di Desa Bangsal Kecamatan Pampangan. Riau Journal of Empowerment, 3(1), 49-59. https://doi.org/10.31258/raje.3.1.4959

Darnis F dan Azdy RA. 2019. Pemanfaatan Media Informasi Website Promosi (e-Commerce) sebagai Upaya Peningkatan Pendapatan UMKM Desa Pedado. Seminar nasional Hasil Pengabdian Kepada Masyarakat 2019 , Pontianak.

Ferdinandus S dan Wijaya F. 2020. Pelatihan Pembuatan dan Pengelolaan Web Blog Bagi Pengabdian Masyarakat. Jamak (Manajemen \& Akuntansi), 03(01)

Hasugian PS 2018. Perancangan Website Sebagai Media Promosi Dan Informasi. Journal of Informatic Pelita Nusantara, 3(1). 
Nurfathiyah, P., J. Marsal dan T. Aminoto. 2018. Pengembangan Media Pemasaran (Website) Produk Pertanian di Desa Tangkit Baru Kecamatan Sungai Gelam Muaro Jambi. Jurnal Karya Abdi Masyarakat, 2(2),112-123. https://doi.org/10.22437/jkam.v2i2.6088

Putera, J. M., Irwansyah, M. A., dan A. S. Sukamto. 2019. Rancang Bangun Aplikasi Berbasis Android dengan Penerapan Web Service pada Sistem Informasi Perpustakaan (Studi Kasus: Perpustakaan Daerah Kalimantan Barat). Jurnal Sistem dan Teknologi Informasi (JUSTIN), 5(1).

Riyanto, A. D., dan M. F. Noeris. 2018. Pelatihan Pemanfaatan Media Sosial Sebagai Media Promosi Online untuk Pelaku UMKM di Cilacap. Jurnal Pengabdian Kepada Masyarakat (J-ABDIPAMAS), 2(2), 53-57. http://dx.doi.org/10.30734/j-abdipamas.v2i2.236

Sutrisno, T., dan Trisnawarman, D. 2018. Pembuatan Dan Implementasi Website Desa Pendowoharjo. Jurnal Bakti Masyarakat Indonesia, 1(2), 211-220.

Yulida, R., Kurnia, D., Andriani, Y. and Restuhadi, F. 2020. Pelatihan Penggunaan Website untuk Meningkatkan Literasi Media Petani Kelapa Sawit Di Desa Kiyap Jaya Kecamatan Bandar Sei Kijang Kabupaten Pelalawan Provinsi Riau. Jurnal ABDINUS: Jurnal Pengabdian Nusantara, 3(2), 306-316.

https://doi.org/10.29407/ja.v3i2.13850 